\title{
METABOLISM IN Amaranthus L. SEEDS AFTER THEIR TREATMENT WITH ELECTROCHEMICALLY ACTIVATED WATER
}

\author{
O.A. Pasko \\ Tomsk National Research Polytechnical University, Tomsk 634050, Russia \\ e-mail: oap@sibmail.com \\ Received June 9, 2010
}

$\mathrm{S} \mathrm{um} \mathrm{mary}$

Numerous data confirm the high effect of electrochemically activated water application in agriculture. Nevertheless, the mechanisms of such effect are still not described in detail. The author studied the influence of preplant treatment of amaranth seeds by electrochemically activated water on activity of respiratory enzymes, the substrates content, the germination energy and the growth strength. It was established, that physico-chemical changes of water after electrolysis induce in seeds different metabolic processes. High content of soluble sugars on the background of anaerobiosis in variants with mixture cathodic and anodic liquors and catholyte only promotes to glycolytic process, but accumulated metabolite pool permit to use them in more various chemical conversions. The increased content of hormones accelerates the growth processes, determines enhanced division and cell distension, the intensive course of initial stages of plant development (increase of germination energy and growth strength in seeds).

Keywords: electrochemically activated water, metabolism, seeds, growth and development, stimulation, inhibition, mechanism.

Bioactive properties of electrochemically activated water (EAW) are being studied since 1965 (1). Using EAW for presowing treatment of cucumber seeds, it was found to improve the quality of seedlings, yield and immunity of plants, as well as a product quality. Later, the efficiency of EAW was confirmed on maize, buckwheat, millet, sunflower, oats, wheat, barley, sweet peppers, tomatoes, radish, lettuce, onions, and cabbage (2-4).

Seed treatment with EAW has opened great prospects for growing medicinal plants with prolonged innate seed dormancy (5). This method allows growing plants from seeds with expired storage period or germination period not corresponding to a growing season of species in conditions of growing. For example, seeds of ginseng treated with EAW manifested 2-4 times higher germination power and rate, lower incidence of diseases (up to 0 points), and faster germination (by half a month). Anolyte (acidic modification of EAW) is effectively utilized in reclamation of alkaline soil (6), so it makes unnecessary to deliver acids right to the treated area and improves the efficiency of soil treatment (7). There is evidence that discrete alternated watering with catholyte (alkaline modification of EAW) and anolyte reduces water consumption by $10 \%$ and mineral depletion by $20 \%$ (8). Using anolyte is 500 times cheaper than chemical preservatives of foreign and domestic production. In silage, it provides $98 \%$ preservation while the increase of nutritional value by $7-12 \%$, in vegetables, fruits, and berries - 93-98 \% (for 5-7 months) (9). Along with it, anolyte is widely used as a disinfectant (10-14).

High efficiency of EAW in agriculture has been practically proved (15-17), however, the mechanism of its action on biological objects is yet not described $(18,19)$. In this regard, the author have planned and performed a series of experiments revealing the direction and intensity of metabolic processes in germinating seeds after the pre-sowing seed treatment of electrochemically activated water.

Technique. Electrolysis of water was performed in a diaphragm electrolyzer with flat graphite anode, titanium cathode, and a neutral canvas dam, under a constant voltage of $200 \mathrm{~V}$. To obtain the mixture of catholyte and anolyte (hereinafter CA-mix) as the most effective EAW modification, the freshly prepared solutions were mixed in a ratio 50:50 \% vol. (14). Levels of pH and Eh were measured on a pH-meter pH-673 (Russia) with platinum-point electrode EPV-1 and silver-chloride electrode EVL-1MZ. The content of dissolved oxygen was determined on an oxygen meter KL-N5 (Russia); carbon dioxide, $\mathrm{CO}_{3}{ }^{2-}, \mathrm{HCO}_{3}^{-}, \mathrm{Cl}^{-}, \mathrm{Mg}^{2+}$ ions, and total hardness of water - by volumetric analysis (20). Concentration of $\mathrm{Cl}_{2}, \mathrm{SO}_{4}{ }^{2-}$ was determined by means of turbidimetry, $\mathrm{NO}_{3}{ }^{-}, \mathrm{NO}_{2}{ }^{-}$, $\mathrm{Fe}^{2+}, \mathrm{Fe}^{3+}$ - colorimetrically (21). All measurements were performed in four series of 8 replicates each one.

A model object was foxtail amaranth (Amaranthus caudatus L.) whose seeds were treated by soaking for 10 hours in tap water (control), catholyte, anolyte, and in CA-mix (soaking time was established in preliminary tests).

Cytokinin activity was studied in 3-day-old seedlings. Content of the hormone was determined from the proportional correlation between the content of cytokinin-active substances and biosynthesis of $\beta$-cyanines in the extract of plant tissues (22). Concentration of amaranthine was found spectrophotometrically (23), as well as the contents of metabolic substrates - malate, lactate, and pyruvate. The activity of oxidative enzymes NADH and NADPH-isocitrate dehydrogenase (NADH-IDH and NADPH-IDH), NAD-malate dehydrogenase (NAD-MDH), glucose-6-phosphate dehydrogenase (GPDH), and alcohol dehydrogenase (ADH) were determined spectrophotometrically from changes in the ratio NAD/NADPH (24). In seedlings it also was measured the concentration of saccharides and soluble proteins (21).

To study the influence of EAW on germinative power of seeds, they were treated with CA-mix and then placed in moistened rolls of filter paper, each rolled of three bands with the size $20 \mathrm{~cm} \mathrm{~S} 100 \mathrm{~cm} \mathrm{(25):} \mathrm{two} \mathrm{bands} \mathrm{were} \mathrm{underlying} \mathrm{substrate} \mathrm{for} \mathrm{seeds,} \mathrm{and}$ the third was a cover. The rolls with seeds were placed in containers with a small amount of distilled water, thermostated $\left(\mathrm{t}=20^{\circ} \mathrm{C}\right)$, kept in the dark for 7 days, and then unrolled to estimate the development of seedlings. Germinative power of seeds was determined from the ratio: number of strong seedlings (estimated as 4 and 5 points) / total number of seeds, germination rate - from the arithmetic mean of 4 samples each of 100 seeds (at deviation of characters not exceeding $5 \%$ ).

The obtained data were statistically calculated using software packages DATAS-COPE and SAS.

Results. The scheme of the used electrolyzer is shown on Figure 1.

A comparative physico-chemical analysis of the various modifications of EAW has revealed significant changes caused by treatment of water (Table 1). In these solutions $\mathrm{pH}$ varied from 3.1 to 10.4 , and Eh - from +420 to $-860 \mathrm{mV}$. There was a corresponding variation in form and amount of carbon dioxide: in catholyte disappeared free carbon dioxide while a maximum

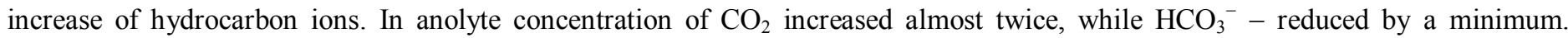


Significantly increased the content of $\mathrm{SO}_{4}{ }^{2-}$ and $\mathrm{Cl}^{-}$. In catholyte $\mathrm{HCO}_{3}{ }^{-}$completely disappeared, but appeared $\mathrm{CO}_{2}$. Concentration of $\mathrm{Cl}^{-}, \mathrm{SO}_{4}{ }^{2-}, \mathrm{Ca}^{2+}, \mathrm{NO}^{3-}, \mathrm{Mg}^{2+}$ greatly reduced.

1. Physico-chemical characteristics of electrochemically activated water used in the experiment

\begin{tabular}{l|r|c|c|c|c|c|c}
\hline \multirow{2}{*}{ Modification } & \multirow{2}{*}{$\mathrm{pH}$} & \multirow{2}{*}{$\mathrm{Eh}, \mathrm{MB}$} & \multicolumn{5}{c}{ Concentration, $\mathrm{mg} / \mathrm{l}$} \\
\cline { 6 - 9 } & & & $\mathrm{HCO}_{3}{ }^{-}$ & $\mathrm{CO}_{3}{ }^{2-}$ & $\mathrm{CO}_{2}$ & $\mathrm{O}_{2}$ & $\mathrm{O}_{2} / \mathrm{CO}_{2}$ \\
\hline Tap water & 6.8 & +200 & 5.2 & - & 2.64 & 9.24 & 3.8 \\
Catholyte & 10.4 & -860 & - & 1.9 & - & 6.83 & - \\
Anolyte & 3.1 & +420 & 0.6 & 5.6 & 5.28 & 12.45 & 2.4 \\
Catholyte-anolyte mixture 1:1 & 6.8 & -200 & 2.0 & - & 2.60 & 9.71 & 3.7 \\
\hline N o t e. Dashes mean the absence of a compound.. & & & & & & \\
\hline
\end{tabular}

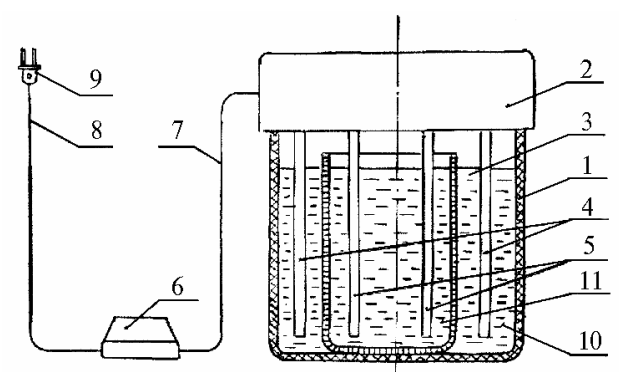

Fig. 1. Scheme of electrolyzer: 1 - tank shell, 2 anode, 3 - cathode, 4 - canvas dam, 5 and 6 inductances, 7 and 8 - ac voltage terminals, 9 single-phase receiver with input terminals of ac voltage 10 and $11(10-$ connected to ac voltage terminal 8 , 1 - with free terminal of the inductance 6 and the two output terminals of unipolar pulsating voltage).

2. Content of metabolites in germinating seeds of Amaranthus caudatus L. after the presowing treatment with electrochemically activated water $\left(X_{ \pm} x\right)$

\begin{tabular}{l|c|c|c|c}
\hline \multicolumn{1}{c|}{ Parameter } & Control & Catholyte (C) & Anolyte (A) & CA-mix (C+ A) \\
\hline Soluble protein, mg/g wet weight & $7.8 \pm 0.1$ & $7.8 \pm 0.2$ & $7.3 \pm 0.1$ & $8.3 \pm 0.2$ \\
Sucrose, $\mathbf{u g} / \mathrm{ml}$ & $4.3 \pm 0.1$ & $8.5 \pm 0.2^{*}$ & $3.8 \pm 0.1$ & $8.6 \pm 0.1^{*}$ \\
Reducing saccharides, $\mathrm{ug} / \mathrm{ml}$ & $16.5 \pm 0.4$ & $21.1 \pm 0.5^{*}$ & $15.2 \pm 0.4^{*}$ & $27.0 \pm 0.5^{*}$ \\
Malate, umol/g wet weight & $0.2 \pm 0.1$ & $0.7 \pm 0.1$ & $0.2 \pm 0.1$ & Traces \\
Lactate, umol/g wet weight & $0.3 \pm 0.1$ & $0.6 \pm 0.1^{*}$ & $0.2 \pm 0.1$ & $0.6 \pm 0.2^{*}$ \\
Pyruvate, umol/g wet weight & $0.8 \pm 0.2$ & $1.0 \pm 0.2^{*}$ & $1.0 \pm 0.1^{*}$ & $0.6 \pm 0.2$ \\
\cline { 1 - 1 } * Differences are reliable at 5\% significance level. & & & &
\end{tabular}

At the very beginning of swelling, seeds in all variants showed no significant differences in water absorption rate, which appeared only after 18 hours of treatment. In the variants with catholyte and CA-mix there was observed enhanced cell division correlated with cytokinin content, for anolyte - decline of these parameters. The content of auxins increased after the treatment with catholyte and CA-mix, and reduced after anolyte treatment (Table 2, Fig. 2).

The analysis of soluble proteins, sucrose, and reducing saccharides showed the increase of proteolytic and hydrolytic decomposition in the variants with catholyte and CA-mix, and a relative suppression of these processes in the variant of anolyte. Treatment with CA-mix increased the content of reducing sugars, soluble protein, lactate, and reduced - malate and pyruvate. In tests with intact water (control) and anolyte, there were found close levels of malate and lactate, as well as significant difference in pyruvate content.
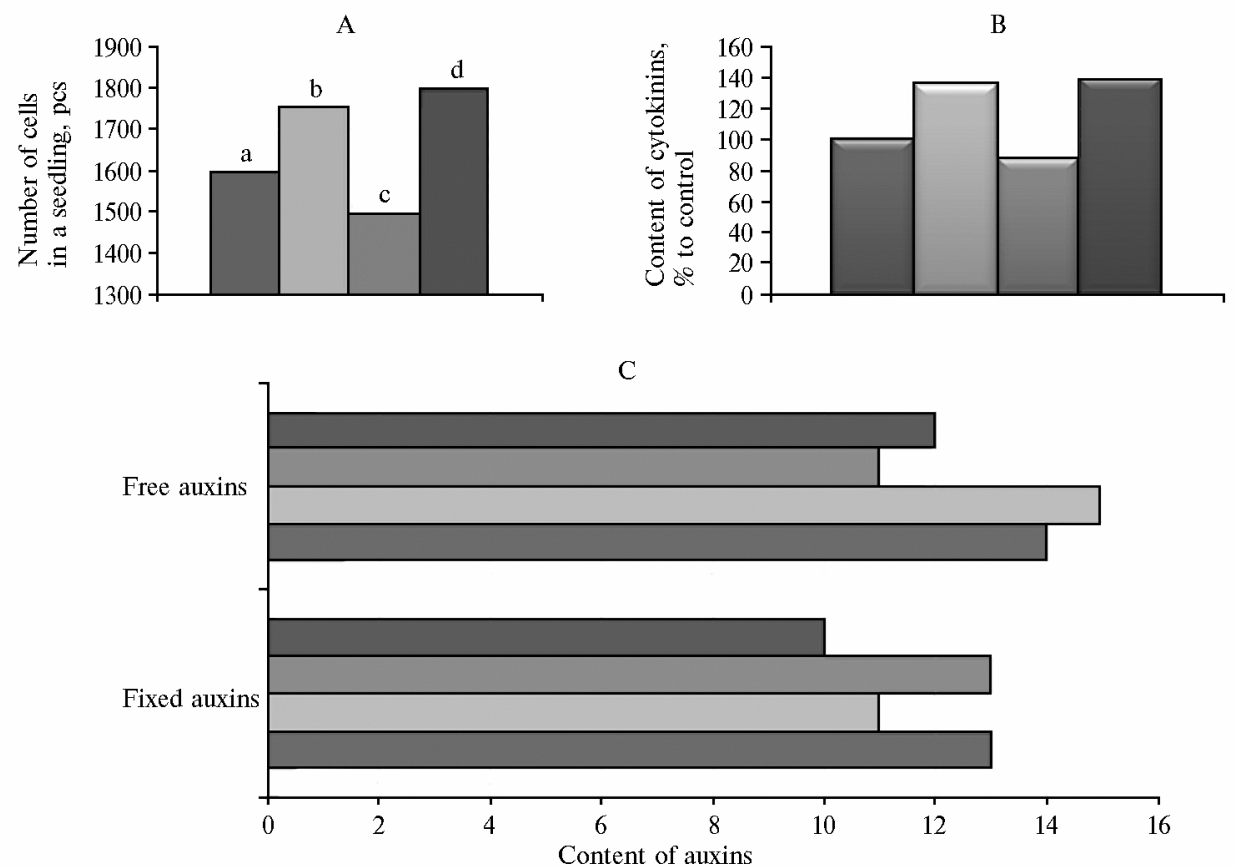

Fig. 2. Number of cells (A), content of cytokinins (B) and auxins (C) in tissues of germinating seeds of $\mathrm{Ama}$ ranthus caudatus $\mathrm{L}$. after the pre-sowing seed treatment with tap water (control, a) and electrochemically activated water $(\mathrm{b}$ - catholyte, $\mathrm{c}$ - anolyte, $\mathrm{d}$ - catholyte-anolyte mixture).

In the all variants, seed treatment with EAW significant reduced the activity of NAD-IDH and NAD-MDH (maximum - for CA-mix: respectively, from 784.5 to 711.6 and from 57.0 to $19.7 \mathrm{mU} / \mathrm{g}$ wet weight). The activity of NADP-IDH remained almost 
unchanged, while activity of NADH-ADH grew more than 3 times. Elevated activity of NADP-GPDH in the variants of catholyte and CA-mix indicated the reactions of pentose phosphate pathway (PPP). In the variant of CA-mix there occurred final stages of alcoholic fermentation, as was shown by increased activity of NADH-ADH. The content of key metabolites varied in accordance with the activity of enzymes that control their metabolism (Table 2).

Previously it was shown that CA-mix provides the maximum stimulating effect on plants $(3,4,10)$. In this work, a detailed study of physiological parameters of the seedlings has revealed much greater share of strong seedlings (2.7 times) and much smaller amount of weak (1.8 times) ones after EAW treatment. The effect was manifested in a more powerful development of roots and aboveground organs (Table 3 ).

3. Germinative power of seeds of Amaranthus caudatus L. (by share of seeds at different developmental stages, \%) after the pre-sowing seed treatment with catholyte-anolyte mixture (CA-mix)

\begin{tabular}{l|c|c|c|c|c}
\hline \multicolumn{1}{c}{ Variant } & $\begin{array}{c}5 \text { points } \\
(\mathrm{Lr}-40-50) \\
(\mathrm{Ls}-30-40)\end{array}$ & $\begin{array}{c}4 \text { points } \\
(\mathrm{Lr}-30-40) \\
(\mathrm{Ls}-20-30)\end{array}$ & $\begin{array}{c}3 \text { points } \\
(\mathrm{Lr}-20-30) \\
(\mathrm{Ls}-10-20)\end{array}$ & $\begin{array}{c}2 \text { points } \\
(\mathrm{Lr}-10-20) \\
(\mathrm{Ls}-5-10)\end{array}$ & $\begin{array}{c}1 \text { point } \\
(\mathrm{Lr}-0-10) \\
(\mathrm{Ls}-0-5)\end{array}$ \\
$\begin{array}{l}\text { Control } \\
\text { CA-mix }\end{array}$ & $\begin{array}{l}11 \\
\text { N o t e. Germinative power of seeds was assessed by the 5-point rating of their development (1-5): 1 and 2 points - weak seed- }\end{array}$ \\
lings, 3 points - medium-developed seedlings, 4 and 5 points - strong seedlings. Lr - length of a radicle, Ls - length of a \\
sprout, mm.
\end{tabular}

Considering results of own researches, as well as the literature data (3, 10, 26-28), the author proposes the following mechanism of action of EAW on metabolic processes in seeds (Fig. 3).

Catholyte is a strong alkaline medium with $\mathrm{Eh}=-800 \mathrm{mV}$ and reducing properties in chemical reactions; in interaction with biological molecules catholyte acts as an electron donor. Anolyte is an acidic substance with Eh $=+300 \mathrm{mV}$ and oxidative properties. Treatment with anolyte increases transmembrane electric potential, while catholyte or CA-mix reduce it. In contact with the cell membrane, anolyte causes a proton-motive force (PMF) oriented into the cells, in contrast to catholyte and CA-mix that cause PMF of an opposite direction.

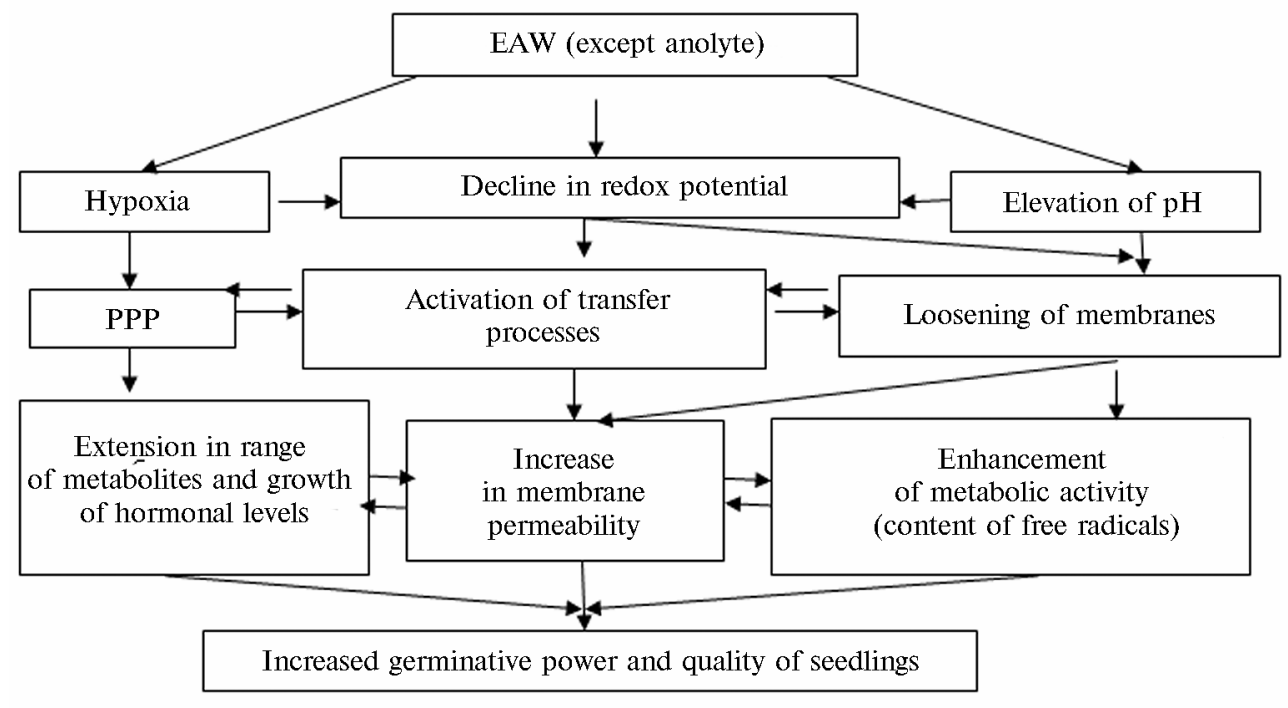

Fig. 3. The proposed scheme of metabolic processes in seeds of Amaranthus caudatus L. induced by electrochemically activated water (EAW): $P P P$ - pentose phosphate pathway

The mechanism of cell division activates enzymes integrated in the outer membrane if PMF exceeds a certain threshold value and directs to the outside of the cell. PMF of an opposite direction deactivates the enzymes and reduces cellular metabolic activity. In the first hours of soaking seeds in water, its entry into the seed is restricted by seed shell. Its subsequent hydrophilization is accompanied by the increase in transfer of catholyte and CA-mix into cells and their hydration. This induces reactivation of soluble enzymes present in seeds at inactive state and triggers corresponding biochemical processes. In tissues with sufficient hydration, accumulated starch granules are being converted into soluble mono- and disaccharides which then are oxidized rapidly in metabolic processes to form various metabolites and released energy. Proteins serve as additional sources of energy in seeds of this species where they constitute from 13 to $21 \%$ dry weight (29).

Before radicle comes off, seed tissues exist in hypoxia and anaerobic respiration. Normally, anaerobic respiration occurs at sufficient oxygen content in the environment as well. Increased soaking of seeds enhances hypoxia and concomitant depletion of reserve substances (sugars and proteins). Decompensation of ATP-producing processes is evidenced by accumulation of lactate and ethanol, i.e. the development of lactic acid and alcoholic fermentation. Probably, in this case PPP is a compensatory mechanism that provides a reducing agent; its inclusion allows the formation of three-, four-, five-, six- and seven-carbon saccharides and much wider variety of metabolites.

Catholyte is the most oxygen-poor kind of EAW, so it strongly initiates fermentation whose type is determined by $\mathrm{pH}$. Alkaline medium (pH 10.6 and higher) "overlaps" the first stage of alcoholic fermentation - decarboxylation of pyruvate (optimal medium for pyruvate decarboxylase - slightly acidic) and stimulates the activity of LDH and lactic acid fermentation. In CA-mix, $\mathrm{pH}$ is close to the optimum of most of the investigated enzymes (for ADH optimum pH = 7.6, for LDH - 8.5) (30).

In the variants of CA-mix and catholyte, high content of soluble saccharides at anaerobic conditions also contributed to the development of glycolytic processes. Normal maintenance of glycolysis necessitates oxidation of NADH that occurs against the reduction of lactate to pyruvate by $\mathrm{LDH}$, or aldehyde - to alcohol. Final products of fermentation at small amounts efficiently 
stimulate germination of seeds, while ethanol serves as activator or analog of the hormones.

Usually NAD is an oxidizing agent in catabolic reactions, while a reducing agent in anabolic reactions is NADPH provided by PPP. In the common view, increased participation of PPP in oxidative processes improves their total energetic efficiency. In PPP doesn't occur the formation of compounds with macroergic bonds, though increases the rate of oxidation of glucose-6-phosphate and the synthesis of NADP and pentoses that stimulate metabolic activity of cells. PPP also promotes the synthesis of hormones (31). High levels of hormones accelerate growth processes, they enhance cell division and distension, as well as an intense passage of early developmental stages (increased seed vigor and germinative power).

When radicle emerges out of a seed and raptures a seed shell, it switches metabolic processes from anaerobic to aerobic pathway in both EAW-stimulated and control seeds. The accumulated pool of metabolites in stimulated seeds allows utilizing them in a greater variety of chemical transformations.

These data are well correlated with results of the own author's studies $(3,10,19)$. The intensity of metabolism in germinating seeds of amaranth estimated from the content of free radicals was maximum in the variant with CA-mix and minimum - for anolyte. This proves the fact of enhanced metabolic activity in tissues of seeds caused by EAW treatment, increased activity of redox reactions playing a significant role in glycolysis and aerobic processes, i.e., reactions whose intermediates are free radicals. In turn, it is known that products of free radical oxidation control permeability of cell membranes, stimulate cell growth and growth rate of plants (32).

Thus, the direction and intensity of metabolic processes in germinating seeds are determined by physical and chemical characteristics of water. The accumulated pool of metabolites allows using them in wide variety chemical transformations. Elevated levels of hormones accelerate growth processes, stimulate cell division and distension, and provide intense passage of early stages of plant development.

The author expresses the most sincere appreciation to A.V. Semenov, L.N. Shiyan, and T.P. Astafurova for assistance in conducting the experiments.

\section{REFERENCES}

1. Obraztsov S.V., Marshunina A.M., Cherepanov V.N. Issledovanie vliyaniya fizicheskikh faktorov na urozhainost' ovoshchnykh kul'tur, razrabotka i vnedrenie polupromyshlennykh ustanovok [Study of the Influence of Physical Factors on Productivity of Vegetable Crops, Development and Application of Semi-Industrial Devices]. Tomsk, 1983.

2. Alekhin S.A. Sokrashchenie vegetatsionnogo perioda, uskorenie rosta rastenii i uvelichenie urozhainosti sadovo-ogorodnykh kul'tur s ispol'zovaniem elektroaktivirovannykh vodnykh rastvorov [Shorter Growing Season, Faster Growth, and Increased Productivity of Horticultural Crops Promoted by Electroactive Water Solutions]. Tashkent, 1992.

3. Pas'ko O.A. Ekologicheskie aspekty povysheniya produktivnosti tsvetochnykh i ovoshchnykh kul'tur i kartofelya v taezhnoi zone Zapadnoi Sibiri. Doktorskaya dissertatsiya [Ecological Aspects of Improving the Productivity of Ornamental and Vegetable Crops in Taiga Zone of Western Siberia. DSc Thesis]. Novosibirsk, 2000.

4. Zelepukhin I.D., Pas'ko O.A., Asenova E.K. Primenenie aktivirovannoi vody v sel'skom khozyaistve i biotekhnologii (analiticheskii obzor) [The Use of Biologically Active Water in Agriculture and Biotechnology: Analytical Review]. Tomsk, 2006.

5. Grodzinskii A.M., Lebeda A.F., Pendus N.I. et al. Sposob predposevnoi obrabotki semyan s glubokim organicheskim pokoem. A.s. № 1207412 SSSR, MKI3 A 01 S 1/00. Opubl. 30.01.86. Byul. № 7 [The Method of Pre-Sowing Treatment of Deeply Dormant Seeds, Inventors Certificate № 1207412 USSR, MKIZ A 01 S 1/00,

Publ. 30.01.86, Bull № 7].

6. Shumakov B.B., Martynenko G.N., Khoruzhenko I.R. Sposob melioratsii pochv zasolennogo ryada. A.s. № 990146, MKIZ A O 25/00, S 09 K 17/00. Opubl.

23.01.83. Byul. № 3 [The Method for Melioration of Saline Soils,Inventors Certificate №990146, MKIZ A O 25/00, S 09 K 17/00, Publ. 23.01.83, Bull № 3].

7. Goncharenko S. Tekhnika i nauka, 1982, 10: 5.

8. Pronov V.I. Sposob poliva. A.s. № 1034658, MKI3 A 01 O 25/00. Opubl. 15.08.83. Byul. № 30 [The Method of Watering Plants, Inventors Certificate 1 1034658,

MKIZ A 01 O 25/00, Pub1. 15.08.83, Bull. №30]

9. Elektrokhimicheskaya aktivatsiya vodnykh rastvorov i ee tekhnologicheskoe primenenie v pishchevoi promyshlennosti (Obzornaya informatsiya)[Electrochemical

Activation of Water Solutions and Its Technological Utilization in Food Industry: Review]. Tbilisi, 1988, v. 3.

10. Pas'ko O.A., Gomboev D.D. Aktivirovannaya voda $i$ vozmozhnosti ee primeneniya v rastenievodstve $i$ zhivotnovodstve [Activated Water and Its Utilization in Plant Industry and Animal Husbandry]. Tomsk, 2011.

11. Bakhir V.M., Leonov B.I., Prilutskii V.I., Shomovskaya N.Yu.

Vestnik novykh meditsinskikh tekhnologii, 2003, 4: 78-80.

12. Gomboev D.D. Doklady RASKHN, 2007, 2: 45-47.

13. Zakomyrdin A.A. Veterinariya, 2002, 2: 12-14.

14. Pas'ko O.A. Voda: khimiya i ekologiya, 2010, 7: 45-47.

15. Pas'ko O.A. Trudy Tomskoi gosudarstvettoi sel'skokhozyaistvennoi opytnoi stantsii [Sci. Works of Tomsk State Experimental Agricultural Station], 2000: $216-220$.

16. Red'kin G.A., Semenov A.V., Pas'ko O.A. Vliyanie predposadochnykh obrabotok semennogo materiala termicheski i elektrokhimicheski aktivirovannoi vodoi na urozhainost' kartofelya. Materialy Pervoi regional'noi nauchno-prakticheskoi konferentsii «Kartofel'v Sibiri» [Proc. I Regional Sci.-Pract. Conference «Potato in Siberia»]. Tomsk, 2001: 53-57.

17. Razrabotka ekologicheski chistykh metodov uvelicheniya rezul'tativnosti rastenievodstva (otchet po NIR «Rezul'tat») [Development of Ecologically Safe Methods for Improving Outcomes of Plant Growing: Report on R\&D Project

«Result»]. Tomsk, 1993.

18. Pas'ko O.A., Ketskalo V.M. Fiziologiya rastenii, 1991, 38(2): 381-385.

19. Pas'ko O.A. Fiziologiya i biokhimiya kul'turnykh rastenii, 1991, 23(6): 552-556.

20. Unifitsirovannye metody analiza prirodnykh vod /Pod obshchei redaktsiei Yu.Yu. Lur'e [Unified Methods of Water Analysis. Yu.Yu. Lur'e (ed.)]. Moscow, 1979.

21. Ermakov A.I., Arasimovich V.V., Smirnova-Ikonnikova M.I. et al. Metody biokhimicheskogo analiza rastenii [Methods for Biochemical Investigation of Plants]. Leningrad, 1972.

22. Fiziologiya i biokhimiya prorastaniya semyan (Perevods angliiskogo)/Pod redaktsiei M.G. Nikolaevoi, N.V. Obruchevoi [Physiology and Biochemistry of Plant

Germination. M.G. Nikolaeva, N.V. Obrucheva (eds.)]. Moscow, 1982.

23. Bradford M.M. A rapid and sensitive methods for the quantities of protein utilizing the principle of protein-dye binding. Analyt. Biochem., $1976,72: 248-254$.

24. Yuzbekov A.K. Spektrofotometricheskie sposoby opredeleniya aktivnosti klyuchevykh fermentov dykhatel'nogo metabolizma rastenii: Metodicheskoe poso-

bie [Spectrophotometric Measurements of Activity of the Key Enzymes of Plant Respiratory Metabolism: Guidelines]. Kiev, 1990.

25. Likhachev B.S. Sila rosta semyan (teoriya, metody, znachenie). Avtoreferat doktorskoi dissertatsii [Seed Germination Capacity: Theory, Methods, and Importance.

DSc Thesis]. Krasnodar, 1986.

26. Danovich K.N., Sobolev A.M., Zhdanova L.P. et al. Fiziologiya semyan[Physiology of Seeds]. Moscow, 1982.

27. Zeleneva I.V., Vladimirov S.V. Fiziologiya i biokhimiya kul'turnykh rastenii, 1994, 26(5): 93-97.

28. Chirkova T.V. Puti adaptatsii rastenii k gipoksii i anoksii [Plants' Adaptation to Hypoxia and Anoxia]. Leningrad, 1988.

29. Rastitel'nye resursy SSSR. Tsvetkovye rasteniya, ikh khimicheskii sostav i ispol'zovanie [Plant Resources of USSR. Flower Plants: Chemical Composition and Use]. Leningrad, 1985: 217-218.

30. Lenindzher A. Biokhimiya. Perevods angliiskogo [Biochemistry]. Moscow, 1984.

31. Khavkin I.E. Formirovanie metabolicheskikh sistem v rastushchikh kletkakh rastenii [Formation of Metabolic Systems in Growing Plant Cells]. Novosibirsk, 1977.

32. Zhuravlev A.I. Bioantiokisliteli v regulyatsii metabolizma v norme i patologii[Bio-Antioxidants in Regulation of Metabolism in Normal State and Pathology:

Compilation of Sci. Works]. Moscow, 1982: 3-30. 